\title{
Social Media as Entrée into Special Collections Reference Works
}

I shall hand on my fatherland not less, but greater and better.

Oath of the Ephebes

\section{Introduction}

Librarians in our segment of the profession have an obligation to prepare not only the next generation of librarians, but also the next generation of collectors and scholars who engage with rare books and archival material. This preparation, in which librarians join with a community of scholars and teachers, can take many forms; employ myriad strategies; and impart diverse skills. Among the skills we share are the physical evaluation of the book itself as an object, placing the object into the historical and social context in which it was created, and intellectual interrogation of the source itself. None of these skills can be employed to their fullest potential without the use of rare book and archival reference sources. This paper will demonstrate the value of reference works for undergraduates in the special collections environment and propose a method by which students can be actively engaged in learning about these valuable resources and the skills necessitated in their use. Specifically, we suggest that undergraduates working in a special collections environment can learn how to use rare book reference works by using them as sources for social media posts that highlight collection items.

The value of reference works — and their utility—is well understood by the readers of this journal. We, as a community of practitioners and scholars, see the inherent value of these skills. However, these sources—and their concomitant skills-are rarely taught to undergraduates, though this knowledge can be transformative in the intellectual work and life of a student. Undergraduates who desire a career in special collections or rare book librarianship must be introduced to special collections reference works. Even students who are not interested in such employment but who have scholarly interest in the fields of history, literature, linguistics, art, and the like may find use for these resources in their own research.

However, such reference works are at best a mystery to undergraduate students. When the average college students hear the word "bibliography," they likely think of the enumerative bibliographies that follow a body of research. In the words of

*(C) 2017 by Jason W. Dean and Emily Grover (CC BY-NC [https://creativecommons.org/ licenses/by-nc/4.0/]). 
Terry Belanger, an enumerative bibliography is a listing of books "according to some system or reference plan" describing "the author's name, the book's title, and date and place of publication" without any details of the physical characteristics of the book. ${ }^{1}$ In the experience of coauthor and recent undergraduate Grover, many of her fellow students thought of bibliography as a research product rather than a research tool. They did not use bibliographies; they created them following the citation guidelines of the Modern Language Association, Chicago, American Psychological Association, ${ }^{2}$ or some other citation format and attached them to the end of research papers. Enumerative bibliographies were not essential to their scholarly arguments; rather, they were guards against plagiarism in a research paper. Descriptive bibliographies may initially seem strange to undergraduates because they are separated from a body of research and describe the intricate physical details of books. Undergraduates working in rare book or special collections environments need to understand the basic differences in format and function between enumerative and descriptive bibliography. While there may be numerous ways to approach this issue of introducing and teaching descriptive bibliography, the authors of this paper propose that using social media may be one of the most beneficial and enriching ways to do so.

As discussed above, the concept of bibliography is foreign to most undergraduates; unfortunately, it is becoming increasingly so to graduate-level library school students. Grolier Club Director Eric Holzenberg once lamented that "descriptive bibliography and the history of the book... are seldom addressed in library school curricula increasingly - and perhaps inevitably—dominated by courses on information science and the manipulation of the digital universe." ${ }^{3}$ We do not intend to denounce the use of digital sources but to reassert the skill of using printed bibliographies and reference works. We hope to point a way forward for learning and teaching reference sources for researching materials held in special collections by using social media.

\section{Dean:}

We at Southwestern University Special Collections are developing and implementing rare book reference work education for our undergraduate student workers by encouraging them to use the reference skills and sources they have learned to describe and share collection material on social media. The university's Special

1. Terry Belanger, "Descriptive Bibliography," in Book Collecting: A Modern Guide, ed. Jean Peters (New York: R.R. Bowker, 1977), 99.

2. MLA Handbook 8th Edition (New York: Modern Language Association of America, 2016); The Chicago Manual of Style, 16th Edition (Chicago: University of Chicago Press, 2010); Publication Manual of the American Psychological Association, Sixth Edition (Washington, D.C.: American Psychological Association, 2013).

3. Eric Holzenberg, "Bridging the Gap: Education and Special Collections-The 46th RBMS Preconference," RBM (Spring 2006): 12. 
Collections Department is known for its strength in items related to Texas, especially colonial and Republic-era Texas. Specifically, we house the Edward A. Clark Texana Collection, which began in 1965 as a gift of 2,400 titles from Ambassador Clark and has grown to a collection of 6,861 titles. As a Texas-centric collection, we work with key Texas bibliographies, including Thomas W. Streeter's five-volume Bibliography of Texas ${ }^{4}$ as well as John H. Jenkins' Basic Texas Books. ${ }^{5}$ Also important are The New Handbook of Texas, ${ }^{6}$ both in print and online; ABC for Book Collectors; ${ }^{7}$ Sid Berger's The Dictionary of the Book: A Glossary for Book Collectors, Booksellers, Librarians, and Others; ${ }^{8}$ ancillary materials from several Rare Book School courses; ${ }^{9}$ and the Oxford Companion to the Book. ${ }^{10}$ With these resources, the student workers have the basic tools to gain a broad understanding of many of the titles in the Clark Collection, and they use them frequently in the course of their work. Our student workers perform a wide range of tasks-from shelving to mounting full-scale exhibitions - but one of the most important duties in the context of this article is their work posting about our collection items via our departmental social media accounts. These reference works also form a basis for the research that our undergraduates conduct for our social media posts.

Students are introduced to the reference materials in special collections during their orientation to the department, then receive more formal instruction later. This initial introduction is by necessity and choice, as a new student worker is expected to ingest a great deal of information during their orientation. The addition of in-depth instruction in reference sources would make this orientation overly burdensome. Also, further instruction in those sources comes after the new student worker has gained some familiarity with the collections and is ready to generate content for the departmental social media accounts.

The formal instruction time is facilitated through several methods. First is a website and physical handout containing information on the most important reference works for researching items in Special Collections at Southwestern-including the aforementioned Bibliography of Texas, the New Handbook of Texas, and Basic Texas

4. Thomas W. Streeter, Bibliography of Texas, 1795-1845 (Cambridge: Harvard University Press, 1955).

5. John Holmes Jenkins, Basic Texas Books: An Annotated Bibliography of Selected Works for a Research Library (Austin, Tex.: Texas State Historical Association, 1988).

6. Ronnie C. Tyler, Douglas E. Barnett, and Roy R. Barkley, The New Handbook of Texas (Austin: Texas State Historical Association, 1996).

7. John Carter, Nicolas Barker, and Simran Thadani, John Carter's ABC for Book Collectors (New Castle, Del.: Oak Knoll Press, 2016).

8. Sidney E. Berger, The Dictionary of the Book: a Glossary for Book Collectors, Booksellers, Librarians, and Others (Lanham, Md.: Rowman \& Littlefield, 2016).

9. These courses include Joel Silver's Reference Sources for Researching Rare Books; Tom Congalton, Katherine Reagan, and Johan Kugelberg's Developing Collections.

10. Michael F. Suarez and H.R. Woudhuysen, The Oxford Companion to the Book (Oxford: Oxford University Press, 2010). 
Books. Second is the intentional selection of items from our collections that -at first glance-appear to be uninteresting to the student. However, during an exercise in which the student uses reference works to find more information about the item, the student discovers the story behind the item and why it resides in a special collection. Finally, and implied above, is the use of objects in hand from our collections, as well as the use of the applicable physical reference works.

For example, J. Evetts Haley's The XIT Ranch of Texas is used in this exercise. The 1929 Lakeside Press edition of the book, though attractive, looks much like other books of the period. The student, drawing on their knowledge of reference sources that pertain to Texas books, selects Jenkins' Basic Texas Books, knowing that Streeter's work chronologically excludes all books printed after 1845. In the description that Jenkins provides of the book, the student can select the 1929 edition (Jenkins gives this particular title number 82 in Basic Texas Books) and discover that this edition is scarce in the marketplace due to a libel suit brought against Haley after the publication of the work. Going beyond Jenkins, the student then examines the physical volume and its bookplates_-researching each known owner, including Haley himself. This process highlights for students that books and special collections items often have compelling stories associated with them that are not evident on first viewing. These stories make the object more engaging and compelling to the student, as well as the wider public through social media.

With our reference sources and knowledge of how to use them, our student workers are well equipped to begin researching materials that will be posted on our social media accounts, primarily Tumblr and Instagram. Our goal is for much of this research to be student-driven; students choose what collection items or topics they want to post to social media. This practice not only gives them a greater sense of ownership over what they produce for our institution, but it also allows them to apply what they have learned about rare book reference sources to their own individual interests.

\section{Grover:}

I chose to post on Tumblr about fine press books produced by the Grabhorn Press in the early twentieth century. This particular set of books interested me as a history major because the Grabhorns were known for reprinting famous histories and primary accounts. I saw my fellow student workers similarly perform research related to their interests and majors for their Tumblr posts. One worker majoring in English chose to focus on fine press fictional literature, and another studying fine arts focused on books with exceptional illustrations. We felt that our posts benefited from this diversity of interests among our students because our online audiences were exposed to a greater variety of materials. 


\section{Dean:}

Having an online presence is becoming increasingly necessary for academic special collections to reach potential researchers both on and off campus. These platforms are more image-driven, and, in the case of Tumblr, students can write more indepth explanations of their images in a microblogging format. As many readers of this journal already know, working in special collections requires our students to learn the physical and visual elements of the book. Some elements are more difficult to visualize than others (for example, folding patterns), but by posting images of the special visual elements of rare books to social media and providing a written explanation, our students have become more comfortable and confident in their ability to "read" a book for its physical attributes. In turn, they become more literate in descriptive bibliography and retain that knowledge better. Therefore, social media that focus on images not only give our viewers an appealing glance at the items in our collections, but they also help our students learn rare book research and description in an innovative way.

\section{Grover:}

We as students have enjoyed using social media to research our collection items and connect to more diverse audiences. This practice has encouraged us to use rare book reference skills and has expanded our knowledge in our chosen fields of study. It has also benefited the institution as a whole because it can invest more time in a social media presence and incorporate our unique and diverse perspectives. Indeed, my fellow student workers and I have shown great enthusiasm for using rare book reference sources to post research to social media. Even if we were not intrinsically motivated, there are some fundamental benefits that come with regularly posting such research to social media, including the opportunity to exercise essential professional skills. First, we critically analyze multiple sources and extract the most relevant information. Second, we communicate by writing succinct and accessible content that maintains a professional level of spelling and grammar. These skills transfer to many jobs and career fields. Finally, posting to social media for an institution is a relatively easy way for us to publish our own brief writing, alleviating some of the trepidation that comes with publication. Most undergraduates do not have the time or the resources to invest in a research project worthy to be published in a peer-reviewed academic journal. And though social media posts are not nearly of the same caliber as journal articles, they demonstrate at least some competency with writing academic material for public and scholarly audiences alike. (Speaking from personal experience as a recent college graduate entering the job market, practicing these skills has given me more confidence in my ability to communicate efficiently with public audiences, whether I'm writing technology guides for library patrons or explaining the various patterns and techniques of Depression-era glassware in exhibit labels.) 
I would like to close with a testimonial to the efficacy of the Southwestern University brand of rare book education. While interning at the Library of Congress in the summer of 2016, I was asked to take on the project of indexing RBSC's collection of travel narratives published by the de Bry firm in the late sixteenth and early seventeenth centuries. Anyone familiar with the de Bry collection of voyages knows it is one of the most complex compilations of European exploration narratives ever published. The corpus involves around 50 original authors, multiple printers, multiple languages, and multiple editions. As I began to sort through the books, I was handed a convenient but relatively simplistic de Bry bibliography created by a historian as an appendix to his research. The scholar provided some solid historical context, but he did not go into enough detail for me to differentiate the various editions of a de Bry work. I looked online, but the sources were so spotty that I felt my time was wasted in searching the Internet.

Then I remembered my experience using bibliographies to post rare book material on social media. Without prompting from any of my colleagues, I immediately took the initiative to search for de Bry bibliographies in the division's reference section, and I found exactly what I needed: Bibliotheca Americana: Catalogue of the John Carter Brown Library in Brown University, Providence, Rhode Island ${ }^{11}$ and A Catalogue of Books Relating to the Discovery and Early History of North and South America Forming a Part of the Library of E.D. Church. ${ }^{12}$ These rare book bibliographies became my best friends throughout my indexing project. Nearly all of the explanations and details that I needed to understand the collection were covered in those books. I was a faster and more efficient worker because I found those resources and knew how to use them. They enabled me to index more than 200 of the library's de Bry works while working on another major project and completing minor day-to-day tasks in a span of ten weeks. I seriously doubt I would have had that instinct to look for those reference sources if I had not been exposed to them as an undergraduate through our program, and I found the education all the more enriching because I got the opportunity to share my discoveries through social media.

\section{Conclusion}

With support and in the right circumstances, students discover not only the "how" and "why" of bibliographies and reference resources (how and why to use them), but also the potentially transformative knowledge they now have within their grasp - knowledge that applies not only to books and book history, but also to their own interests as burgeoning scholars. This learning and acquisition of skills is facili-

11. Bibliotheca Americana: Catalogue of the John Carter Brown Library in Brown University, Providence, Rhode Island, 1919-1931.

12. George Watson Cole and Elihu Dwight Church, A Catalogue of Books Relating to the Discovery and Early History of North and South America Forming a Part of the Library of E.D. Church (New York: Peter Smith, 1951). 
tated through and made more seamless to the student by the use of social media as a tool to teach them rare book and archival reference sources. Their initial interest in an item in the collection leads them to want to know more about the itemboth to satisfy their own curiosity and to be able to share about the item on social media. Furthermore, users of these social media channels gain knowledge of the items in Special Collections' collections, leading to greater use of these items and increased interest in the department. It falls to us, then, to pass on these skills to the next generation of scholars, to hand down our profession in a way that makes it "greater and better" than it was in the past, or is in the present.

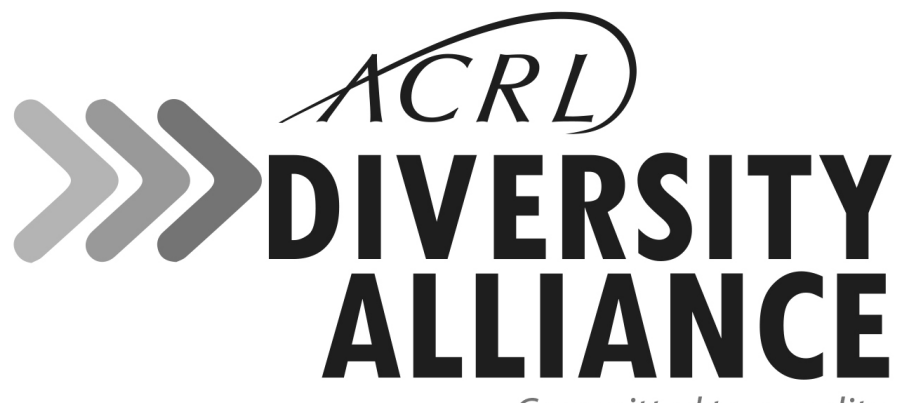

Committed to equality

\section{Join the ACRL Diversity Alliance today!}

ACRL invites libraries to join its effort to promote diversity in the profession.

By establishing residency programs for individuals from underrepresented backgrounds, member institutions help create a more fully representative applicant pool for positions in academic and research libraries.

Benefits to institutions include:

- Participation in an effort to improve the pipeline of diverse individuals who will compete for academic and research library jobs.

- Access to other Alliance institutions and coordinator insights, job postings, and residency rotation schedules.

- A digital badge, to be placed on your institution's website, recognizing its commitment to the Alliance's principles.

- Attracting a more diverse candidate pool, by including your institution's membership in the Alliance in job postings.

To learn more about the Alliance and how your library can join this initiative visit: http://www.ala.org/acrl/diversityalliance 